\title{
The Psychopharmacology Algorithm Project at the Harvard South Shore Program: 2012 Update on Psychotic Depression
}

\author{
Michael Tang ${ }^{1}$, David N. Osser ${ }^{2}$
}

\section{ÖZET:}

Harvard South Shore Programı'ndaki psikofarmakoloji algoritma projesi: Psikotik depresyon güncellemesi 2012

Giriș: Harvard South Shore Programı'ndaki Psikofarmakoloji Algoritma Projesi (PAPHSS), 1998 ve 2000 yıllarında, psikotik özellikli majör depresyonun (psikotik depresyon) farmakolojik tedavisi için kanıt destekli algoritmalar yayınlamıştır. Bu makale, 2008 algoritması için bir güncellemedir.

Yöntem: 2008 güncellemesinde kullanılana benzer yöntem kullanılarak, PubMed ve EMBASE taraması yapıldı. Illgili İngilizce literatür, Kasım 2007'den ve Temmuz 2012'ye kadar tarandı. Makaleler, verilerin niteliãine ve mevcut önerilere ek kanıt destek sag̃layıp sag̃lamadıg̃ına ya da önceki algoritmada deg̃işikliklere sebep olup olmadıg̃ına göre deg̃erlendirildi.

Bulgular: Algoritmada küçük deg̃ișiklikler yapıldı, önceki önerilerin cog̃u desteklendi. Elektrokonvulsif tedavi (EKT), hastaneye yatırılmış, ag̃ı psikotik depresyon hastaları için en etkin tedavi olmaya devam etmektedir. EKT mevcut olmadıăında veya düsünülmedig̃inde tercih edilen farmakolojik yöntem ise halen bir antidepresan (trisiklik [TSA], seçici serotonin geri-alım engelleyici [SSGE] veya serotonin-norepinefrin geri-alım engelleyici [SNGE]) ile bir antipsikotiãin birlikte kullanımıdır. Son güncellemeden itibaren yeni kanıtlar, ilk seçenek antidepresan olarak bir SNGE olan venlafaksin ER kullanımını destekleme eãilimindedir. Antipsikotikler ele alındıg̃ında, hem olanzapinin hem de ketiapinin etkililiãini gösteren yeni veriler mevcuttur. Ancak daha iyi huylu güvenlik profillerine sahip dig̃er atipik antipsikotiklerin (örn. ziprasidon, aripiprazol) ilk secenek antipsikotik olarak denenmesinin daha akıllıca olacag̃ı tavsiye edilmektedir. Yeni veriler ayrıca en az dört aylık idame tedavisinin de etkin oldug̃unu önermektedir. Ẽ̃er ilk antidepresan-antipsikotik birlikte kullanımı tatminkar bir sonuc vermezse ve EKT hala ulaşılabilir veya uygun deg̃ilse ikinci farmakolojik girişim, 2008 algoritmasında da önerildig̃i gibi, antidepresanda deãisiklik yapmak olabilir. İki birlestirme girișimi basarısız olduktan sonra (ve yine EKT tercihler arasında yoksa) algoritma, lityum eklenmesini önermeye devam etmektedir. Sınırı miktarda kanıt, klozapin tekli tedavisine gecmeyi de tavsiye etmektedir. Çok küçük miktardaki kanıta dayanan metilfenidat eklenmesi ise son dönemde bahsedilen, olası bir seçenektir. Kanıtlar, birlestirme tedavisi tercih edilmediãinde, TSA ile tekli tedavinin SSGE ile veya SNGE ile tekli tedaviden daha etkin oldug̃unu önermektedir. Ancak, güvenlik konuları ve psikoz alevlenmesi riskinde olası artıs, TSA tekli tedavisi icin olumsuz etkenlerdir. Antidepresan tekli tedavisi bașarısız olursa, EKT veya bir antipsikotik eklenmesi yeniden deg̃erlendirilmelidir.

Sonuc: Bu gözden gecirme, psikotik depresyonun farmakolojik tedavisi icin mevcut olan kanıtların önceki PAPHSS analizini yeniden deg̃erlendirmektedir. Sonuçların geçerliliãi, mevcut literatürün nicelik ve nitelig̃i açısından kısıtıdır. Psikotik depresyonda birebir karșılaștırmalı ileriye dönük çalıșmalar halen görece az miktardadır. Ancak bu algoritma, psikotik depresyon tedavisi için hekimlere bir rehber olarak hizmet edebilir.

Anahtar sözcükler: mizaç bozuklug̃u, psikotik, psikotik depres yon, sanrısal depresyon, farmakolojik tedavi, psikofarmakoloji

Journal of Mood Disorders 2012;2(4):168-79

\section{ABSTRACT:}

The psychopharmacology algorithm project at the harvard south shore program: 2012 update on psychotic depression

Background: The Psychopharmacology Algorithm Project at the Harvard South Shore Program (PAPHSS) has published evidence-supported algorithms for the pharmacological treatment of major depressive disorder with psychotic features (psychotic depression) in 1998 and 2008. This article is an update for the 2008 algorithm.

Method: Using similar methodology as with the 2008 update, PubMed and EMBASE searches were conducted to identity relevan literature in the English language from November 2007 through July 2012. Articles were evaluated for quality of the data and for whether they provided additional evidence support for previous recommendations or prompted changes to the prior algorithm.

Results: Minor changes were made to the algorithm: most prior recommendations were upheld. The most effective treatment for hospitalized, severe psychotic depression patients remains electroconvulsive therapy (ECT). The combination of an antidepressant (tricyclic [TCA], selective serotonin reuptake inhibitor [SSRI], or serotonin-norepinephrine reuptake inhibito [SNRI]) plus an antipsychotic continues to be the preferred pharmacological modality when ECT is an unavailable/deferred option. Since the last update, new evidence tends to support using venlafaxine ER, a SNRI, as the first choice antidepressant. Regarding the antipsychotic, both olanzapine and quetiapine have new data demonstrating efficacy. Nevertheless, it is suggested that it may be reasonable to try other atypica antipsychotics with more benign safety profiles (e.g ziprasidone, aripiprazole) as the first choice antipsychotic. New data also suggest at least four months of maintenance therapy is effective. If the first antidepressant-antipsychotic combination produces an unsatisfactory outcome, and ECT is still not acceptable or appropriate, the second pharmacotherapy trial can be with a change in the antidepressant, as was recommended in the 2008 algorithm. After two trials of combination therapy have failed (and, again, ECT is not an option), the algorithm continues to recommend augmentation with lithium. Limite evidence also suggests consideration of a switch to clozapine monotherapy. Augmentation with methylphenidate is a newly mentioned possible option based on very small evidence. When combination therapy is deferred, evidence suggests monotherapy with a TCA may be more effective than an SNRI or SSRI. However, safety issues and possible increased risk of psychosis exacerbation are unfavorable factors for TCA monotherapy. ECT or addition of an antipsychotic should be reconsidered if antidepressant monotherapy failed.

Conclusion: This heuristic further refines the previous PAPHSS analysis of the available evidence for pharmacological treatment of psychotic depression. The validity of the conclusions is limited by the quality and quantity of the literature available: the number of head-to-head prospective trials in psychotic depression is still relatively small. However, this algorithm may serve as a guide for clinicians in the management of psychotic depression.

Key words: affective disorders, psychotic, psychotic depression, delusional depression, pharmacological treatment, psychopharmacology

Journal of Mood Disorders 2012;2(4):167-79
${ }^{1} \mathrm{DO}$, Harvard Medical School; VA Boston Healthcare System, Brockton Division, Brockton, MA

'MD, Harvard Medical School; VA Boston Healthcare System, Brockton Division, Brockton, MA

Yazıșma Adresi / Address reprint requests to: David N. Osser, MD, VA Boston Healthcare System, Brockton Division, 940 Belmont Street, Brockton, MA 02301

Telefon / Phone: 774-826-1650

Faks / Fax: 774-826-1655

Elektronik posta adresi / E-mail address: David.0sser@va.gov

Kabul tarihi / Date of acceptance: 9 Aralık 2012 / December 9, 2012

\section{Bag̃ıntı beyanı}

M.T., D.N.O.: Yazarlar bu makale ile ilgili olarak herhangi bir çıkar çatışması bildirmemiștir.

Declaration of interest: M.T., D.N.O.: The authors reported no conflict of interest related to this article. 


\section{INTRODUCTION}

The pharmacological management of psychotic depression has varied among clinicians, and debate regarding the optimum approach is ongoing. The Psychopharmacology Algorithm Project at the Harvard South Shore Program (PAPHSS) created and published evidence-supported heuristics for the use of medication in psychotic depression in 1998 and $2008(1,2)$. This article serves as an update to the 2008 algorithm.

It is estimated that psychotic depression occurs in $14 \%-18 \%$ of all patients with depressive episodes $(3,4)$, and in approximately $25 \%$ of patients hospitalized for major depressive disorder (5). However, there is evidence of diagnostic instability when patients are followed longitudinally. In a 10-year prospective study by Ruggero and colleagues (6), 80 subjects initially diagnosed with psychotic depression by the DSM-IV criteria were followed. Only 36 (45\%) retained the original diagnosis at year 10, while $11(14 \%)$ were diagnosed with bipolar disorder and 33 (41\%) had a non-mood disorder at year 10. In another study, Tohen and colleagues conducted a two-year follow up of 56 patients with first-episode psychotic depression (7). Seven dropped out of the study, 29 (59\%) retained their initial diagnosis, and the other 20 changed to a diagnosis of either bipolar disorder (14/20) or schizoaffective disorder (6/20). Given such statistics, clinicians should remember that initial diagnosis is only provisional, and the subsequent course may result in a change in diagnosis and in the indicated psychopharmacology.

\section{METHODS}

This algorithm update is one of several recently published by the PAPHSS (1, 8-11) and available in condensed format for access on smart phone devices on the website www.psychopharm.mobi. The methods of producing these algorithms have been described in the previous publications. For this psychotic depression update, the authors utilized similar methodology to the 2008 update, in which PubMed and EMBASE searches were conducted to identify relevant studies, metaanalyses, practice guidelines, and reviews in English from November 2007 through July, 2012. Articles were evaluated for the quality of the evidence, and whether they either added support for previous conclusions of the PAPHSS algorithm or called for reconsideration or change of recommendations.

The algorithm is depicted in Figure 1. It focuses on psychopharmacological treatment of psychotic depression and does not address psychotherapy treatment options. Arabic numerals refer to "nodes" in the algorithm flowchart, and each node is reviewed below with discussion of the pertinent evidence and its limitations.

\section{NODE 1: IF SEVERELY ILL, HAVE YOU CONSIDERED ELECTROCONVULSIVE THERAPY?}

The algorithm starts with questioning the patient's appropriateness for electroconvulsive therapy (ECT) as the initial treatment. Consistent with the 2008 algorithm, ECT is still to be considered for hospitalized, severely ill patients, as it may be the most effective treatment for psychotic depression. However, the supporting data are all from uncontrolled studies. In an observational study by Petrides and colleagues, 77 subjects with psychotic depression receiving bilateral ECT achieved a remission rate of $95 \%$, based on the 24-item Hamilton Depression Rating Scale (HAM-D-24) versus $83 \%$ in nonpsychotic depressed patients; $(n=176), p<.01$ (12). In a chart review comparing 14 patients receiving ECT and 12 unmatched patients receiving antidepressant plus antipsychotic combination, $86 \%$ of ECT patients received a favorable overall response as compared to $42 \%$ of patients in the combination group $(\mathrm{p}<0.05)$ (13). This study had a small sample size, and ECT was compared to different combinations with varying doses and treatment periods.

Other uncontrolled studies found ECT to have better response rates than pharmacological management. Olfson and colleagues found that ECT is more rapidly effective than pharmacotherapy, shortens hospital stays, and reduces treatment costs if initiated within five days of admission (14).

However, ECT still remains to be compared randomly and prospectively in acute treatment with any medication regimen, and the duration of ECT effect still remains unclear (15).

Although this algorithm mainly focuses on acute management of psychotic depression, it is worth noting a new maintenance treatment study by Navarro and 


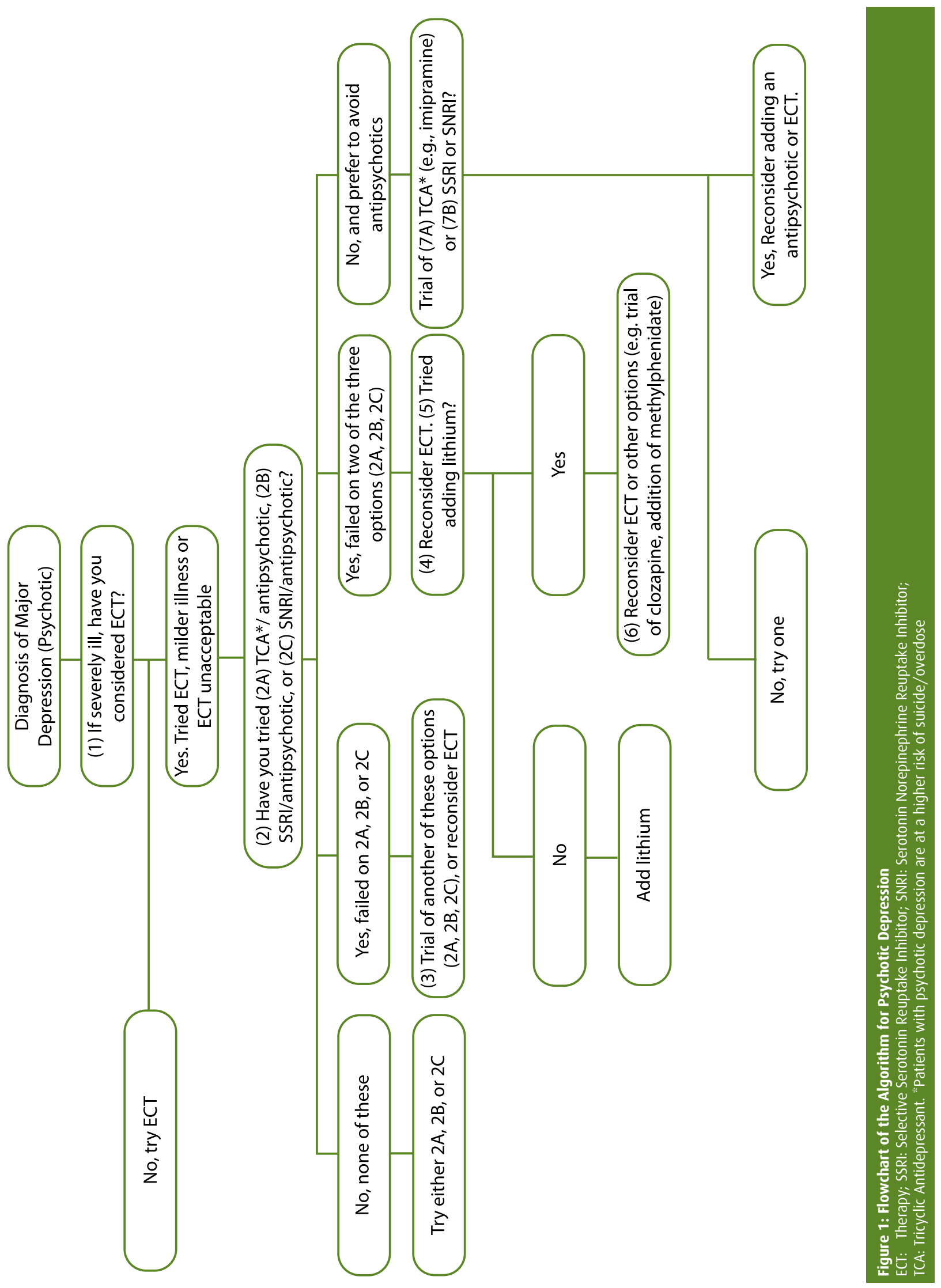


colleagues that reflects positively on the role of ECT (16). It was a 2-year randomized, single-blind study of patients age 60 orgreaterinitially treated with ECT and nortriptyline, followed by either nortriptyline monotherapy $(n=16)$ or ECT plus nortriptyline $(n=17)$. The nortriptyline monotherapy group also was given 6 weeks of risperidone up to $2 \mathrm{mg}$ daily. Results showed 5/17 patients on nortriptyline monotherapy did not have a recurrence, as compared to $11 / 16$ in the ECT plus nortriptyline group $(p=0.009)$. Both groups had 4 dropouts. Limitations to the study included its small sample size and the inclusion of only older subjects. Also, it would have been of interest to have a comparison group of patients maintained on combined antidepressant plus antipsychotic.

Despite its apparent effectiveness, ECT has several problems including its limited availability and its side effects, most notably memory impairment. Also, some studies have also reported a high relapse rate in psychotic depression after a good response to $\operatorname{ECT}(17,18)$. In addition, patients and families may refuse ECT treatment, or patients may not be good candidates because of comorbid medical conditions.

\section{NODE 2: HAVE YOU TRIED (2A) TRICYCLIC ANTIDEPRESSANT PLUS ANTIPSYCHOTIC, (2B) SELECTIVE SEROTONIN REUPTAKE INHIBITOR PLUS ANTIPSYCHOTIC, OR (2C) SEROTONIN NOREPINEPHRINE REUPTAKE INHIBITOR PLUS ANTIPSYCHOTIC?}

When the patient has a milder presentation, refuses ECT, or is not a suitable candidate for ECT, pharmacological management is recommended by the 2010 American Psychiatric Association (APA) Practice Guideline (19) and the 2009 British National Institute for Clinical Excellence (NICE) guideline (20). The 2008 PAPHSS algorithm (1), the APA practice guideline, and a recent meta-analysis by Farahani et al (21) suggest that psychotic depression typically responds better to combination therapy with an antidepressant plus an antipsychotic than to monotherapy with either antidepressant or antipsychotic. The most recent update (2009) of the Cochrane collaboration meta-analysis on psychotic depression (22), however, continues to suggest that antidepressant monotherapy should be the initial offering and then combination antidepressant/ antipsychotic therapy if the patient is not responding to antidepressant alone. They emphasize the potential for adverse effects associated with combination therapy. In this algorithm update, combination therapy still continues to be the first-line recommendation. We will evaluate the evidence related to these different opinions.

\section{Node 2A: The Combination of a Tricyclic Antidepressant and an Antipsychotic}

As described in the 2008 version of the PAPHSS algorithm (1), below are some key studies pertinent to the issue of whether tricyclic antidepressant (TCA) and antipsychotic combination has a better treatment response as compared with TCA monotherapy.

In 1985, Spiker and colleagues conducted what may be considered the landmark pharmacotherapy study for psychotic depression with 51 delusional depression patients (23). Delusional depression is somewhat different from the current DSM-IV concept of psychotic depression, as was described in the previous algorithm paper (1). Patients were randomized for six weeks to either amitriptyline plus perphenazine combination therapy $(n=18)$, amitriptyline monotherapy $(n=17)$, or perphenazine monotherapy $(\mathrm{n}=16)$. Results showed combination therapy to have a $78 \%$ response rate as determined by the 17-item Hamilton Depression Rating Scale (HAM-D-17), as compared to $41 \%$ for amitriptyline monotherapy and $19 \%$ for perphenazine monotherapy ( $\mathrm{p}$ $<0.01)$. Limitations to the study included small sample size, the absence of a placebo group, and the fact that after taking into account several dropouts, the intent-to-treat analysis did not show a statistically significant benefit of combination therapy over antidepressant alone.

Anton and Burch (24) studied a similar comparison employing 38 inpatient subjects given either amitriptyline plus perphenazine or amoxapine alone for a 4 -week period. Response rates (defined as $>50 \%$ reduction in HAM-D-17) were $81 \%$ for combination therapy and $71 \%$ for monotherapy, a non-significant difference. $76 \%$ of patients on amitriptyline plus perphenazine had an improvement on the Brief Psychiatric Rating Scale (BPRS) of more than $50 \%$, compared to $59 \%$ of the patients on amoxapine. This difference was also non-significant. Limitations to the study included its single-blind design, small sample size, and lack of placebo control. 
Importantly, the failure of combination therapy to produce more than a slight numerical advantage over amoxapine could be because amoxapine is actually a combination treatment: its main metabolite has dopamine receptor blocking properties and is probably an antipsychotic (1).

In another study with 35 delusionally depressed patients given desipramine plus perphenazine or plus haloperidol, Nelson and colleagues concluded from their results that both the TCA and the antipsychotic contributed independently to the clinical benefit (25). Responders had an average haloperidol dose of $12 \mathrm{mg} / \mathrm{d}$ versus nonresponders having a daily dose of $6 \mathrm{mg}(\mathrm{p}<.04)$. Perphenazine responders had an average dose over $48 \mathrm{mg}$ daily. The number of responders when desipramine plasma levels were less than $100 \mathrm{ng} / \mathrm{ml}$ was 1 of 8 patients, compared to 15 of 23 patients when the levels were over $100 \mathrm{ng} / \mathrm{ml}(\mathrm{p}<.05)$.

In a randomized double-blind trial by Mulsant and colleagues (26), 52 elderly patients (mean age $=72$ ) were initially started on nortriptyline monotherapy for a two week period This was followed by addition of either perphenazine $(n=17)$ or placebo $(n=19)$ for two more weeks. Response was defined as a HAM-D-17 score of less than 10 and remission of psychotic symptoms on the BPRS. Results showed $44 \%$ responding during initial nortriptyline monotherapy treatment. In the remaining period (with each group having 3 dropouts), response was seen in $50 \%$ $(\mathrm{n}=7)$ of the nortriptyline plus perphenazine group, and $44 \%(\mathrm{n}=7)$ in the nortriptyline plus placebo group-a nonsignificant difference. Limitations of the study included small sample size and a population of elderly and demented patients that might have reduced response rates.

In their meta-analysis of the question of combination therapy versus TCA monotherapy, the Cochrane review considered only two of these four studies: Spiker et al and Mulsant et al. They found no significant advantage for the combination (relative risk ratio $=1.44 ; 95 \%$ confidence interval, $0.86-2.41 ; \mathrm{p}=0.16$ ). However, these two studies had small sample sizes, dissimilar patient populations (average age of 72 versus average age of 44 ), and different methodologies (e.g. - timing of initiating combination therapy). In the 2008 PAPHSS algorithm, it was noted that even with the limitation to these two studies, the numerical advantage for combination treatment appeared large enough to be clinically significant.

\section{Node 2B: The Combination of a Selective Serotonin Reuptake Inhibitor and an Antipsychotic}

Selective serotonin reuptake inhibitors (SSRIs) have displaced TCAs in the treatment of depression in usual practice because of their greater safety. However, some evidence supports the notion that TCAs are superior in efficacy, especially in men and in patients with more severe depression $(27,28)$. In psychotic depression, unfortunately, head-to-head prospective comparisons between an SSRI plus an antipsychotic versus a TCA plus an antipsychotic still have not been done. Below, we briefly review some studies indirectly pertinent to these issues that were discussed in the 2008 algorithm and one new clinical trial.

SSRIs have been combined with both typical and atypical antipsychotics so we will discuss these combinations separately.

\section{SSRIs and typical antipsychotics}

Two small studies examined the combination of an SSRI and a typical antipsychotic.

The first was conducted by Rothschild and colleagues and included 30 patients (meeting DSM-III-R criteria for psychotic depression) treated with a combination of fluoxetine and perphenazine (29). $73 \%$ of the patients (23/30) had a reduction of HAM-D-17 and BPRS scores of $50 \%$ or more after five weeks. Study limitations include open-label design, small sample size, and lack of a placebo control group. Of note, 7/30 of patients carried bipolar diagnoses. The second studywas conducted byWolfersdorf and colleagues with 14 patients treated with paroxetine and either zotepine or haloperidol, or both (30). 3/4 patients receiving combined paroxetine plus haloperidol had a $50 \%$ or more reduction in HAM-D-24. Limitations to the study were its tiny sample size, non-blind design, lack of placebo control, and short 3-week treatment period.

\section{SSRIs and atypical antipsychotics}

Rothschild and colleagues (31) evaluated fluoxetine and olanzapine in two multisite, double-blind, randomized controlled trials (RCTs), with 124 inpatients in trial 1, and 125 inpatients in trial 2. Patients diagnosed with psychotic depression (meeting DSM-IV criteria) were randomized into three groups (placebo, olanzapine 
plus placebo, and olanzapine plus fluoxetine) and treated for an eight-week period. Response was defined as $\geq 50 \%$ decrease from baseline HAM-D-24. Results from trial 1 showed the combination group $(\mathrm{n}=22)$ having a significantly higher response rate (64\%) than the placebo (28\%: $\mathrm{n}=50 ; \mathrm{p}=.004)$ or olanzapine $(35 \%: \mathrm{n}=43 ; \mathrm{p}=.027)$ groups. However, trial 2 showed no significant differences in response among treatment groups (combination $48 \%$; $\mathrm{n}=23$, placebo $32 \%$; $=44: \mathrm{p}=.20$, and olanzapine $36 \%$; $\mathrm{n}=47: \mathrm{p}=.35$ ). Notably, olanzapine alone was not different from placebo in either study, but the $36 \%$ response rate seems higher than the $19 \%$ response rate to perphenazine monotherapy in the landmark Spiker et al study (23). This may be attributed to the possibility that less ill patients would be admitted to the Rothchild et al studies that had a placebo control than to one with all active treatment arms. A limitation of the study was its lack of a fluoxetine monotherapy group. Hence, it did not offer an opportunity to evaluate combination therapy vs. SSRI monotherapy (See Node 7).

Although it did not duplicate the results in trial 1, trial 2 actually had a trend that was possibly clinically significant in favor of combination treatment. The small sample sizes in the combination groups were due to the randomization schedule: the investigators only intended to use the combination group as an "exploratory pilot arm." The primary goal in these industry-sponsored trials was to evaluate olanzapine monotherapy for psychotic depression, and in that respect the results were disappointing.

Since the 2008 update, Meyers, Rothschild, and others published the "STOP-PD" study, a 12 week, double-blind RCT comparing olanzapine $(15-20 \mathrm{mg} / \mathrm{d})$ plus sertraline (150-200 mg/d) versus olanzapine plus placebo for psychotic depression (32). 259 patients were followed with remission as the primary outcome measure. Patients were evaluated weekly for the first 6 weeks, followed by every other week until week 12 . Remission was defined as a HAM-D-24 score $\leq 10$ at 2 consecutive assessments and absence of delusions at the second assessment. Results showed the combination produced significantly more remissions (odds ratio 1.28, 95\% CI 1.12-1.47, p<0.001) than olanzapine alone. $41.9 \%(54 / 129)$ of patients with combination therapy were in remission during their last assessment compared with $23.9 \%$ (31/130) in patients on olanzapine $(\mathrm{p}=0.002)$. As in Rothschild and colleagues' earlier study with olanzapine, this study again lacked an antidepressant monotherapy arm, and it had a high attrition rate $(42 \%)$.

Recently, the authors of this study published an evaluation of the impact of previous medication treatment before study entry (33). They found that if the patient had a prior failed adequate antidepressant monotherapy trial $(n=35)$ and then received combination therapy in the trial, only $20 \%$ responded. By contrast, the 19 patients with no previous treatment who were put on the combination had a $63 \%$ response $(12 / 19)$ vs. $33 \%$ response $(4 / 12)$ if they were put on olanzapine alone. This suggests, despite the small numbers, that in this patient population failure to respond to SSRI monotherapy was associated with a guarded prognosis for adding an antipsychotic. For the treatment-naïve patients, the combination was superior.

In summary regarding the use of SSRIs, the combination of an SSRI plus a typical or an atypical antipsychotic is clearly effective compared with placebo or antipsychotic monotherapy, but there have been no direct comparisons of the combination with SSRI monotherapy. Thus, if an SSRI is chosen as the antidepressant, confidence that combination therapy will be superior to antidepressant monotherapy may be somewhat less than if a TCA is chosen.

\section{Node 2C: The Combination of a Serotonin- Norepinephrine Reuptake Inhibitor and an Antipsychotic}

Since the 2008 update, the first double-blind RCT involving a serotonin-norepinephrine reuptake inhibitor (SNRI) antidepressant (venlafaxine ER) has been published. In this trial, a TCA (imipramine), venlafaxine $\mathrm{ER}$, and a combination of venlafaxine ER plus quetiapine were compared (34). 122 patients were randomized for a 7 week period. Venlafaxine ER dose was $375 \mathrm{mg}$ daily, imipramine was dosed to produce a plasma level of 200$300 \mathrm{ng} / \mathrm{ml}$ of imipramine + desipramine, and the combination involved venlafaxine ER at $375 \mathrm{mg}$ daily and quetiapine at $600 \mathrm{mg}$ daily. Response was defined as greater than a $50 \%$ decrease in the HAM-D-17 score and a final score of less than 15. Remission rates (HAM-D-17 < $8)$ were also examined. The results showed a $66 \%(27 / 41)$ response rate to the combination, $52 \%(22 / 42)$ in the 
imipramine group, and 33\% (13/39) in the venlafaxine ER group. Combination therapy was shown to be more effective than venlafaxine alone (with adjusted odds ratio of $4.02,95 \%$ confidence interval at $1.56-10.32$ ), but there was no significant difference in response when compared with the imipramine group (adjusted odds ratio at 1.76, 95\% CI 0.72-4.30). In remission comparisons, $42 \%$ (17/41) occurred in the combination group, $21 \%(9 / 42)$ in imipramine monotherapy, and $28 \%(11 / 39)$ in venlafaxine monotherapy. The combination was statistically superior only to the imipramine. In linear mixed models analysis, the mean score decrease of HAM-D was numerically (but not statistically significantly) greater with imipramine compared to venlafaxine.

Limitations to the study included lack of a placebo group, remission comparisons done as a post hoc secondary outcome measure, and small sample size. Nevertheless, this study suggests that an SNRI plus antipsychotic combination can be more effective than an SNRI or TCA alone. The study did not provide data on how an SNRI plus an antipsychotic would compare to a TCA or an SSRI plus an antipsychotic.

\section{Nodes 2A, 2B, \& 2C: Conclusions}

Despite the limitations of the data, the authors still find sufficient support to conclude that the combination of an antidepressant and antipsychotic is the first-line psychopharmacological treatment for psychotic depression. However: which antidepressants are preferred?

\section{Antidepressant preference: TCA, SSRI, or SNRI?}

As noted, there are still no head-to-head comparisons of a TCA, SSRI, and SNRI in combination therapy. In our prior update, we presented a detailed effort to make a comparison based on indirect evidence and concluded there was a slight basis for preferring a TCA over an SSRI for effectiveness but a stronger basis to prefer an SSRI for safety including overdose risk (1). We now have some data with an SNRI (venlafaxine ER) in psychotic depression (34). It worked well in combination with an antipsychotic, separating from monotherapy with a TCA and an SNRI on either response or remission. When compared in monotherapy with a TCA, the different trends on response and (secondarily) remission made it difficult to have a preference. Safety concerns would favor venlafaxine over a TCA. In conclusion, venlafaxine has become our first choice for the antidepressant to be used in combination therapy.

There is no evidence to support the favoring of other antidepressant types (e.g. bupropion, mirtazapine, monoamine oxidase inhibitors) in psychotic depression.

\section{Antipsychotic preference}

No direct comparisons are available to test the relative efficacy and safety of different typical and atypical antipsychotics. Our previous analysis of the indirect evidence failed to find any basis for any preference based on effectiveness (1). Since the previous update, as we have noted, quetiapine and olanzapine have new RCTs and both were shown to be effective choices for combination therapy. Quetiapine has more efficacy than olanzapine and other atypical antipsychotics for some other depressive disorders such as bipolar depression (8). This suggests it might be favored (for effectiveness) for psychotic depression.

Regarding safety issues, typical antipsychotics have an increased risk of tardive dyskinesia when compared to atypical antipsychotics especially in mood-disordered psychotic patients (35). Atypical antipsychotics often produce weight gain and related metabolic problems, particularly olanzapine (36). Interestingly, Rothschild's group (37) evaluated the weight gain of 118 patients from their olanzapine and sertraline STOP-PD study, looking for risk factors. Age had a significant negative association with weight gain $(p=0.01)$ even after controlling for differences in cumulative olanzapine dose and baseline body mass index. Each 10-year increase in age was associated with a decrease in mean weight gain over 12 weeks of approximately $0.6 \mathrm{~kg}(\mathrm{p}=0.01)$. The results suggest that olanzapine-induced weight gain is more of a concern in younger patients.

Quetiapine causes weight gain as well, second only to olanzapine in a study in antipsychotic-naïve young patients (38). It also has a new package insert warning in 2011 regarding QTc prolongation and now must receive extra safety monitoring for this and may not be combined with at least 12 specified medications (to which should be added citalopram which has had a similar warning since September, 2011). 
Given that olanzapine and quetiapine are both effective in psychotic depression combination treatment despite their different pharmacodynamic properties (e.g. olanzapine is strongly bound to the dopamine type 2 receptor and quetiapine is loosely bound), it may be reasonable to consider other atypical antipsychotics with a more benign safety profile even if their efficacy has not been as well-demonstrated. Ziprasidone (40-160 mg/d) was combined with sertraline (100 -200 $\mathrm{mg} / \mathrm{d})$ in 19 psychotic depression patients open-label for 4 weeks. 17 completed the study. Patients improved significantly on the HAM-D-21, BPRS, and other rating scales (39). There was no weight gain or prolactin increase, but QTc increased by a mean of $15 \mathrm{~ms}(\mathrm{p}=0.04)$. Aripiprazole was combined with escitalopram in an open-label, 7-week trial (40). Response rate on the 13 completers was $63 \%$ with response defined as a $50 \%$ drop in the HAM-D-17 and no psychosis. Risperidone was combined with an antidepressant in 11 patients as part of an investigation in a heterogeneous population most of whom had psychotic depression and the results seemed promising (41).

\section{Continuation of combination therapy after the acute phase}

Wijkstra and colleagues recently addressed this question in a 4-month follow up study of their comparison of acute treatment with venlafaxine, imipramine, and combined venlafaxine and quetiapine (42). 59 responders (20 patients from imipramine group, 13 from the venlafaxine group, and 26 from the combination group) had their HAM-D-17 measured during open-label follow-up for 4 months. Six dropped out, but $86 \%$ (51 of 59) maintained their response: $16 / 17$ (94\%) of imipramine patients, 12/12 (100\%) on venlafaxine, and 23/24 (96\%) on the combination ( $\mathrm{p}=1.0)$. This study suggests that continuation of treatment with an initially effective medication regimen for at least 4 months is highly recommended.

In an older naturalistic follow-up study, 78 patients who had remitted on combination therapy had a high rate of relapse if they went off their antipsychotics (43). Patients were on the antipsychotics for a mean of 5.0 months but relapsed in a mean of 2.0 months after antipsychotic dosage reduction or discontinuation. Another study in older patients, however, found no differences in relapse rate with antipsychotic discontinuation (17). During a 6-month observation period, 7 of 28 subjects relapsed: 5 of 15 while on combination therapy compared with 2 of 13 on monotherapy $(\mathrm{p}=0.4)$. A recent two-year follow-up study of patients receiving naturalistic treatment after their first diagnosis of psychotic depression found that $45 \%$ experienced new episodes (7). It is unclear if this is because suboptimal treatment was prescribed, patients became non-adherent, or because of confounding changes in diagnosis over time.

In conclusion, this algorithm addresses acute management, and maintenance therapy data are limited. However, the most recent study suggests at least 4 months of maintenance is effective. One should particularly consider the long-term metabolic side effects associated with maintaining the antipsychotic that has received the most study, i.e. olanzapine. If metabolic side effects are significant, it may be worth trying to change to a different antipsychotic or seeing if it can be discontinued.

\section{NODE 3: HAVE YOU TRIED SWITCHING THE ANTIDEPRESSANT IF A FIRST COMBINATION TRIAL HAS FAILED?}

If the patient has had, and failed, an SSRI plus antipsychotic combination, one may consider switching the antidepressant to venlafaxine ER or to a TCA. As noted, this is based on very limited evidence - but it seems there is a little more rationale for this compared with the other option of switching the antipsychotic. If the patient initially failed on venlafaxine plus antipsychotic, close consideration of the conflicting monotherapy data from the Wijkstra et al study (34) suggests it is possible that they might do better on a TCA.

If the patient's initial treatment happened to have been with a TCA plus antipsychotic, there is minor evidence to suggest that a switch to an SSRI or SNRI as the antidepressant might be advantageous. In one study, eight patients with prior failure on full-dose TCA and typical antipsychotic combination therapy showed a $62 \%$ (5/8) response rate after being switched to SSRI plus antipsychotic therapy (29). Blumberger et al found that even after failure on an adequate trial of various (unspecified) combinations of antidepressants and antipsychotics $(n=13), 25 \%$ then responded to the combination of sertraline plus olanzapine, and 
(surprisingly) $40 \%$ of 11 patients responded when assigned to olanzapine monotherapy even though that was not a good treatment for treatment-naïve patients in their study (33). Possibly the diagnoses of these 11 patients were incorrect and they actually had a primary psychotic disorder $(6,7)$.

Thus, though this evidence is very limited, switching antidepressants seems to have some chance of success and it is proposed that this be the next intervention in Node 3.

Reconsideration of ECT should also occur here given its effectiveness in non-responsive patients (44).

\section{NODE 4: IF TWO COMBINATION TRIALS FAILED, AGAIN RECONSIDER ECT}

ECT is probably the treatment of choice after two failed combination trials with different antidepressants. As noted earlier, Blumberger and colleagues found that prior failure to respond to adequate antidepressant courses is associated with poor outcomes with olanzapine and sertraline combination therapy even under research conditions (33). In a study with 15 inpatients with psychotic depression (DSM-III criteria), 8/9 patients who were not responsive to TCA plus antipsychotic combination showed excellent clinical response after ECT (45). In Spiker and colleagues' 1985 study, all six patients failing combination therapy responded well with ECT (23).

\section{NODE 5: DID TWO COMBINATIONS AND ECT ALL FAIL OR WAS ECT UNAVAILABLE OR UNACCEPTABLE?}

Some evidence is available to support augmentation therapy with lithium in this situation. Lithium was used to augment a TCA plus antipsychotic combination in a 20-patient case series, and $40 \%$ had partial or marked response (46). In another augmentation series with 6 unresponsive patients to TCA plus antipsychotic combination, 3/6 had dramatic response and 2/6 had gradual response with lithium (47). Rothschild et al's early study had 3/8 patients responding to lithium augmentation after failing fluoxetine and perphenazine (29). Finally, since the last algorithm update, Birkenhager and colleagues reported on the open-label addition of lithium for 4 weeks to 15 non-responding patients from their venlafaxine/imipramine/quetiapine study (48). They were kept on their blinded initial medications. Nine patients $(60 \%)$ had sustained remission. Five of the 15 patients were on combination therapy but unfortunately their results were not reported separately.

\section{NODE 6: DID TWO COMBINATIONS AND LITHIUM AUGMENTATION FAIL?}

ECT is still considered the best option at the point if not yet tried.

Clozapine may be considered based on evidence derived from case series and case reports. Three patients with refractory psychotic depression, not responding to ECT, had clozapine initiated (49). There was improvement in both psychotic and mood symptoms (response was delayed for 1 patient), and no relapses occurred over a 4-6 year follow up period.

In a case report, a female patient's initial BPRS score of 62 dropped to 39 after 4 weeks of clozapine, and to 21 after four months (50). Another case report described similar results with a female patient whose mood symptoms responded well and psychotic symptoms remitted after receiving clozapine (51)

Since the 2008 update, a new report of an augmentation strategy involving the addition of methylphenidate has appeared. This adds to an old report from over 40 years ago $(52,53)$. In the new case, there was a good effect in a female patient with psychotic depression who had failed on venlafaxine plus olanzapine combination. The patient's family had refused ECT. Her psychosis remitted with a Clinical Global Impression score of 3 and HAM-D score of 8 after 4 days, and she had no recurrence at 2-year follow up.

\section{NODE 7: TCA, SNRI, OR SSRI MONOTHERAPY?}

Sometimes monotherapy with an antidepressant will be preferred (e.g. - due to side effect concerns with antipsychotics). If so, which one should be selected?

\section{Node 7A: TCA Monotherapy?}

TCAs seem to be effective for many cases of psychotic depression. A meta-analysis found TCAs to be superior to 
placebo (54) and to antipsychotic monotherapy (22).

Some evidence suggests TCAs would be preferred over SSRIs. Van Den Borek and colleagues conducted an RCT in depressed patients showing that imipramine at a plasma level of imipramine + desipramine of 192-521 ng/ $\mathrm{ml}$ was more effective than fluvoxamine at 150-1800 mg daily (55). Cochrane analysis of the psychotic depression patients in this study (56) found that $64 \%$ (16/25) of patients on imipramine had $50 \%$ reduction in HAM-D, as compared $30 \%(7 / 23)$ on fluvoxamine $(\mathrm{p}=0.03)$.

In another RCT of depressed patients by Brujin and colleagues, imipramine was shown to be more effective than mirtazapine (57). Cochrane review's analysis of the psychotic depression patients in this study (56) showed that $9 / 15$ patients $(60 \%)$ on imipramine achieved a $50 \%$ reduction in HAM-D scores, as compared to $3 / 15$ patients (20\%) in the mirtazapine group $(\mathrm{p}=0.05)$.

As discussed earlier, the recent RCT comparing the TCA imipramine head-to-head with venlafaxine is hard to interpret because of conflicting data on response and remission (34).

Amoxapine as mentioned earlier has strong typical antipsychotic properties from its metabolite 7-hydroxy amoxapine (24). This product is therefore not recommended due to its possible associated risks for tardive dyskinesia.

\section{Node 7B: An SSRI/SNRI?}

Studies suggesting effectiveness of SSRI or SNRI monotherapy are discussed below. Fluvoxamine (58), sertraline (59), paroxetine (59), and venlafaxine $(34,60)$ all have some evidence.

Zanardi and colleagues conducted a double-blind controlled 6-week study comparing the responses of 66 patients with psychotic depression (DSM-III-R) to sertraline $(n=24)$ and paroxetine $(n=22)(59)$. The HAM-D-21 and the Dimensions of Delusional Experience Rating Scale (DDRS) were utilized for response assessment. $75 \%$ of sertraline patients and $46 \%$ of paroxetine patients responded, but the difference was not statistically significant $(\mathrm{p}=0.16)$. Limitations to the study include lack of placebo group, high dropout rate (41\%) in the paroxetine group, and enrollment of 14 bipolar patients.

Case studies and case series have described the use of fluvoxamine monotherapy (58). In a recent case study a female patient was initially treated with fluvoxamine and risperidone for 1 yearfollowed by fluvoxamine monotherapy maintenance for 2 years (61). At this point, she was switched to sertraline but then developed delusions. Her symptoms resolved after switching back to fluvoxamine. In a case series, 5 patients treated with fluvoxamine all showed reduction in HAM-D and BPRS scores (62).

Zanardi and colleagues conducted another 6-week RCT with 28 inpatients with DSM-IV psychotic depression (60). Subjects received either $300 \mathrm{mg}$ of fluvoxamine or $300 \mathrm{mg}$ of venlafaxine. $79 \%$ of the fluvoxamine group $(n=11)$ and $58 \%$ of the venlafaxine $(n=7)$ showed response with a reduction in HAM-D-21 score to $\leq 8$ and DDERS score of 0 . No statistically significant difference was found between the two drugs $(\mathrm{p}=0.40)$. Limitations to the study included small sample size, lack of placebo control, and enrollment of 6 bipolar patients.

Kantrowitz and colleagues examined the risk for psychosis exacerbation with TCA and serotonergic antidepressant monotherapy in a systemic review on psychotic depression (63). Of the 20 studies reviewed, patients assigned to a tricyclic antidepressant were more likely to experience psychosis exacerbation (8/78) than patients on serotonergic antidepressants (1/93), $\mathrm{p}=0.01$. 6/6 patients treated with MAOIs experienced psychosis exacerbation.

In conclusion, there may be some efficacy for SSRI or venlafaxine monotherapy, but the evidence appears slightly stronger for TCA monotherapy. However, TCAs have the previously noted safety issues and there may also be some increased risk of psychosis exacerbation with TCA monotherapy. The strongest evidence supports initial use of combination therapy with an antidepressant and an antipsychotic, if ECT is not used.

\section{FINAL COMMENTS}

This update to the 2008 PAPHSS algorithm further refines the previous analysis of the available evidence for pharmacological treatment of psychotic depression. However, the validity of the conclusions are limited by the quality and quantity of studies and evidence available. Head-to-head prospective trials in psychotic depression are still relatively few in number. Yet, the alternative to relying as best as possible on this evidence-base would be to make decisions solely on the individual practitioner's 
clinical experience. This can be an unreliable basis for decision-making (64). Andreescu and colleagues in 2007 found that only $57 \%$ of 100 patients with psychotic depression received at least one combination of an antidepressant and an antipsychotic, and only $5 \%$ received a full dose of the antipsychotic (65). Mulsant and colleagues showed similar results in 1997, when $4 \%$ of 53 patients

\section{References:}

1. Hamoda HM, Osser DN. The Psychopharmacology Algorithm Project at the Harvard South Shore Program: an update on psychotic depression. Harv Rev Psychiatry. 2008;16:235-47.

2. Osser DN, Patterson RD. Algorithms for the pharmacotherapy of depression: Part One Directions in Psychiatry. 1998;18:303-18.

3. Johnson J, Jowarth E, Weissman MM. The validity of major depression with psychotic features based on a community study Arch Gen Psychiatry. 1991;48:1075-81.

4. Ohayon MM, Schatzberg AF. Prevalence of depressive episodes with psychotic features in the general population. Am J Psychiatry. 2002;159:1855-61.

5. Coryell W, Lavori P, Endicott J, Keller M, VanEerdewegh M. Outcome in schizoaffective, psychotic, and nonpsychotic depression. Course during a six- to 24-month follow-up. Arch Gen Psychiatry. 1984;41:787-91.

6. Ruggero CJ, Kotov R, Carlson GA, Tanenberg-Karant M, Gonzalez DA, Bromet EJ. Diagnostic consistency of major depression with psychosis across 10 years. J Clin Psychiatry. 2011;72:1207-13.

7. Tohen M, Khalsa HM, Salvatore P, Vieta E, Ravichandran C, Baldessarini RJ. Two-year outcomes in first-episode psychotic depression the McLean-Harvard First-Episode Project. J Affect Disord. 2012;136:1-8.

8. Ansari A, Osser DN. The psychopharmacology algorithm project at the Harvard South Shore Program: an update on bipolar depression. Harv Rev Psychiatry. 2010;18:36-55.

9. Bajor LA, Ticlea AN, Osser DN. The Psychopharmacology Algorithm Project at the Harvard South Shore Program: an update on posttraumatic stress disorder. Harv Rev Psychiatry. 2011;19:240-58.

10. Osser DN, Dunlop LR. The Psychopharmacology Algorithm Project at the Harvard South Shore Program: an update on generalized social anxiety disorder. Psychopharm Review. 2010;45:91-8.

11. Osser DN, Jalali-Roudsari M, Manschreck T. The Psychopharmacology Algorithm Project at the Harvard South Shore Program: an update on schizophrenia. Harv Rev Psychiatry. 2013;21:in press.

12. Petrides G, Fink M, Husain MM, Knapp RG, Rush AJ, Mueller $\mathrm{M}$, et al. ECT remission rates in psychotic versus nonpsychotic depressed patients: a report from CORE. J ECT. 2001;17:244-53.

13. Perry P, Morgan D, Smith R, Tsuang M. Treatment of unipolar depression accompanied by delusions. J Affect Disord. 1982;4:195200. received adequate combination therapy (66). Therefore, this algorithm update hopes to inform clinicians about the evidence available for the psychopharmacology of psychotic depression. It organizes that evidence in a systematic manner, but it is flexible enough in its recommendations to leave ample opportunity to add individual judgment based on clinical experience.

14. Olfson M, Marcus S, Sackeim HA, Thompson J, Pincus HA. Use of ECT for the inpatient treatment of recurrent major depression. Am J Psychiatry. 1998;155:22-9.

15. Keller J, Schatzberg AF, Maj M. Current issues in the classification of psychotic major depression. Schizophr Bull. 2007;33:877-85.

16. Navarro V, Gasto C, Torres X, Masana G, Penades R, Guarch J, et al. Continuation/maintenance treatment with nortriptyline versus combined nortriptyline and ECT in late-life psychotic depression: a two-year randomized study. Am J Geriatr Psychiatry. 2008;16:498-505.

17. Meyers BS, Klimstra SA, Gabriele M, Hamilton M, Kakuma T, Tirumalasetti F, et al. Continuation treatment of delusional depression in older adults. American Journal of Geriatric Psychiatry. 2001;9:415-22.

18. Sackeim HA, Haskett RF, Mulsant BH, Thase ME, Mann JJ, Pettinati HM, et al. Continuation pharmacotherapy in the prevention of relapse following electroconvulsive therapy: a randomized controlled trial. JAMA. 2001;285:1299-307.

19. American Psychiatric Association. Practice guideline for the treatment of patients with major depressive disorder, third edition. Am J Psychiatry. 2010;167:1-118.

20. National Collaborating Centre for Mental Health. The treatment and management of depression in adults: NICE clinical guideline 90. London; Leicester, UK: Gaskell and the British Psychological Society, 2009.

21. Farahani A, Correll CU. Are antipsychotics or antidepressants needed for psychotic depression? A systematic review and metaanalysis of trials comparing antidepressant or antipsychotic monotherapy with combination treatment. J Clin Psychiatry. 2012;73:486-96.

22. Wijkstra J, Lijmer J, Balk FJ, Geddes JR, Nolen WA. Pharmacological treatment for unipolar psychotic depression: Systematic review and meta-analysis. Br J Psychiatry. 2006;188:410-5.

23. Spiker DG, Weiss JC, Dealy RS, Griffin SJ, Hanin I, Neil JF, et al. The pharmacological treatment of delusional depression. Am J Psychiatry. 1985;142:430-6.

24. Anton R, Burch E. Amoxapine vs amitriptyline combined with perphenazine in the treatment of psychotic depression. Am J Psychiatry. 1990;147:1203-8.

25. Nelson JC, Price L, Jatlow P. Neuroleptic dose and desipramine concentration during combined treatment of unipolar delusional depression. Am J Psychiatry. 1986;143:1151-4. 
26. Mulsant BH, Sweet RA, Rosen J, Pollock BG, Zubenko GS, Flynn T, et al. A double-blind randomized comparison of nortriptyline plus perphenazine versus nortriptyline plus placebo in the treatment of psychotic depression in late life. J Clin Psychiatry. 2001;62:597604 .

27. Anderson IM. SSRIS versus tricyclic antidepressants in depressed inpatients: a meta-analysis of efficacy and tolerability. Depress Anxiety. 1998;7 Suppl 1:11-7.

28. Vermeiden M, van den Broek WW, Mulder PG, Birkenhager TK. Influence of gender and menopausal status on antidepressant treatment response in depressed inpatients. J Psychopharmacol. 2010;24:497-502.

29. Rothschild AJ, Samson JA, Bessette MP, Carter-Campbell JT. Efficacy of the combination of fluoxetine and perphenazine in the treatment of psychotic depression. J Clin Psychiatry. 1993;54:33842 .

30. Wolfersdorf M, Barg T, Konig F, Leibfarth M, Grunewald I. Paroxetine as antidepressant in combined antidepressantneuroleptic therapy in delusional depression: observation of clinical use. Pharmacopsychiatry. 1995;28:56-60.

31. Rothschild AJ, Williamson DJ, Tohen MF, Schatzberg A, Andersen SW, Van Campen LE, et al. A double-blind, randomized study of olanzapine and olanzapine/fluoxetine combination for major depression with psychotic features. J Clin Psychopharmacol. 2004;24:365-73.

32. Meyers BS, Flint AJ, Rothschild AJ, Mulsant BH, Whyte EM, Peasley-Miklus C, et al. A double-blind randomized controlled trial of olanzapine plus sertraline vs olanzapine plus placebo for psychotic depression: the study of pharmacotherapy of psychotic depression (STOP-PD). Arch Gen Psychiatry. 2009;66:838-47.

33. Blumberger DM, Mulsant BH, Emeremni C, Houck P, Andreescu C, Mazumdar S, et al. Impact of prior pharmacotherapy on remission of psychotic depression in a randomized controlled trial. J Psychiatr Res. 2011;45:896-901.

34. Wijkstra J, Burger H, van den Broek WW, Birkenhager TK, Janzing JG, Boks MP, et al. Treatment of unipolar psychotic depression: a randomized, double-blind study comparing imipramine, venlafaxine, and venlafaxine plus quetiapine. Acta Psychiatr Scand. 2010;121:190-200.

35. Correll CU, Leucht S, Kane JM. Lower risk for tardive dyskinesia associated with second-generation antipsychotics: a systematic review of 1-year studies. Am J Psychiatry. 2004;161:414-25.

36. Chiu CC, Chen KP, Liu HC, Lu ML. The early effect of olanzapine and risperidone on insulin secretion in atypical-naive schizophrenic patients. J Clin Psychopharmacol. 2006;26:504-7.

37. Smith E, Rothschild AJ, Heo M, Peasley-Miklus C, Caswell M, Papademetriou E, et al. Weight gain during olanzapine treatment for psychotic depression: effects of dose and age. Int Clin Psychopharmacol. 2008;23:130-7.

38. Correll CU, Manu P, Olshanskiy V, Napolitano B, Kane JM, Malhotra AK. Cardiometabolic risk of second-generation antipsychotic medications during first-time use in children and adolescents. JAMA. 2009;302:1765-73.
39. Moeller O, Evers S, Deckert J, Baune BT, Dannlowski U, Nguyen $\mathrm{DH}$, et al. The impact of ziprasidone in combination with sertraline on visually-evoked event-related potentials in depressed patients with psychotic features. Prog Neuropsychopharmacol Biol Psychiatry. 2007;31:1440-3.

40. Matthews JD, Siefert C, Dording C, Denninger JW, Park L, van Nieuwenhuizen AO, et al. An open study of aripiprazole and escitalopram for psychotic major depressive disorder. J Clin Psychopharmacol. 2009;29:73-6.

41. Goto M, Yoshimura R, Kakihara S, Shinkai K, Yamada Y, Kaji K, et al. Risperidone in the treatment of psychotic depression. Prog Neuropsychopharmacol Biol Psychiatry. 2006;30:701-7.

42. Wijkstra J, Burger H, van den Broek WW, Birkenhager TK, Janzing JG, Boks MP, et al. Long-term response to successful acute pharmacological treatment of psychotic depression. J Affect Disord. 2010;123:238-42.

43. Aronson T, Shukla S, Hoff A. Continuation therapy after ECT for delusional depression: a naturalistic study of prophylactic treatments and relapse. Convulsive Therapy. 1987;3:251-9.

44. Schatzberg AF, Rothschild AF. Psychotic (delusional) major depression: should it be included as a distinct syndrome in DSMIV? Am J Psychiatry. 1992;149:733-45.

45. Khan A, Cohen S, Stowell M, Capwell R, Avery D, Dunner DL. Treatment options in severe psychotic depression. Convulsive Therapy. 1987;3:93-9.

46. Price LH, Charney DS, Heninger GR. Variability of response to lithium augmentation in refractory depression. Am J Psychiatry. 1986;143:1387-92.

47. Price L, Conwell Y, Nelson JC. Lithium augmentation of combined neuroleptic-tricyclic treatment in delusional depression. Am J Psychiatry. 1983;140:318-22.

48. Birkenhager TK, van den Broek WW, Wijkstra J, Bruijn JA, van Os E, Boks M, et al. Treatment of unipolar psychotic depression: an open study of lithium addition in refractory psychotic depression. J Clin Psychopharmacol. 2009;29:513-5.

49. Ranjan R, Meltzer HY. Acute and long-term effectiveness of clozapine in treatment-resistant psychotic depression. Biol Psychiatry. 1996;40:253-8.

50. Jeyapaul P, Vieweg R. A case study evaluating the use of clozapine in depression with psychotic features. Ann Gen Psychiatry. 2006;5:20.

51. Dassa D, Kaladjian A, Azorin JM, Giudicelli S. Clozapine in the treatment of psychotic refractory depression. British Journal of Psychiatry. 1993;163:822-4.

52. Huang CC, Shiah IS, Chen HK, Mao WC, Yeh YW. Adjunctive use of methylphenidate in the treatment of psychotic unipolar depression. Clin Neuropharmacol. 2008;31:245-7.

53. Wharton R, Perel J, Dayton P, Malitz S. A potential clinical use for methylphenidate with tricyclic antidepressants. Am J Psychiatry. 1971;127:1619-25. 
54. Khan A, Noonan C, Healey W. Is a single tricyclic antidepressant trial an active treatment for psychotic depression? Progress in Neuro-Psychopharmacology and Biological Psychiatry. 1991;15:765-70.

55. van den BroekWW, Birkenhager TK, Mulder PG, Bruijn JA, Moleman P. A double-blind randomized study comparing imipramine with fluvoxamine in depressed inpatients. Psychopharmacology (Berl). 2004;175:481-6.

56. Wijkstra J, Lijmer J, Balk F, Geddes J, Nolen WA. Pharmacological treatment for psychotic depression. The Cochrane Database of Systematic Reviews, 2004: Art. No.:CD004044.pub2. DOI:10.1002/14651858.CD004044.pub2.

57. Bruijn JA, Moleman P, Mulder PG, van den Broek WW, van Hulst AM, van der Mast RC, et al. A double-blind, fixed blood-level study comparing mirtazapine with imipramine in depressed in-patients. Psychopharmacology (Berl). 1996;127:231-7.

58. Gatti F, Bellini L, Gasperini M, Perez J, Zanardi R, Smeraldi E. Fluvoxamine alone in the treatment of delusional depression. Am J Psychiatry. 1996;153:414-6.

59. Zanardi R, Franchini L, Gasperini M, Perez J, Smeraldi E. Doubleblind controlled trial of sertraline versus paroxetine in the treatment of delusional depression. Am J Psychiatry. 1996;153:1631-3.
60. Zanardi R, Franchini L, Serretti A, Perez J, Smeraldi E. Venlafaxine versus fluvoxamine in the treatment of delusional depression: a pilot double-blind controlled study. J Clin Psychiatry. 2000;61:269.

61. Kishimoto A, Todani A, Miura J, Kitagaki T, Hashimoto K. The opposite effects of fluvoxamine and sertraline in the treatment of psychotic major depression: a case report. Ann Gen Psychiatry. 2010;9:23.

62. Furuse T, Hashimoto K. Fluvoxamine monotherapy for psychotic depression: the potential role of sigma-1 receptors. Ann Gen Psychiatry. 2009;8:26.

63. Kantrowitz JT, Tampi RR. Risk of psychosis exacerbation by tricyclic antidepressants in unipolar Major Depressive Disorder with psychotic features. J Affect Disord. 2008;106:27279-84.

64. Osser DN. Why physicians do not follow some algorithms and guidelines. Drug Benefit Trends. 2009;21:345-54.

65. Andreescu C, Mulsant BH, Peasley-Miklus C, Rothschild AJ, Flint AJ, Heo M, et al. Persisting low use of antipsychotics in the treatment of major depressive disorder with psychotic features. J Clin Psychiatry. 2007;68:194-200.

66. Mulsant BH, Haskett RF, Prudic J, Thase ME, Malone KM, Mann JJ, et al. Low use of neuroleptic drugs in the treatment of psychotic major depression. Am J Psychiatry. 1997;154:559-61. 